\title{
Enamel Protein Regulation and Dental and Periodontal Physiopathology in Msx2 Mutant Mice
}

\author{
Muriel Molla, ${ }^{\star \dagger \neq \S 4}$ Vianney Descroix, ${ }^{* \dagger \ddagger \S}$ \\ Muhanad Aïoub, ${ }^{\star \dagger \ddagger \S}$ Stéphane Simon, ${ }^{*}+\S$ \\ Beatriz Castañeda, ${ }^{\star \dagger \neq \S \|}$ Dominique Hotton, ${ }^{* \dagger \ddagger \S}$ \\ Alba Bolaños, ${ }^{* \dagger \ddagger \S}$ Yohann Simon, ${ }^{* \dagger \neq}$ \\ Frédéric Lezot, ${ }^{* \dagger \ddagger \S}$ Gérard Goubin, ${ }^{* \dagger \S}$ \\ and Ariane Berdal ${ }^{\star} \$ \S \S \pi$
}

\begin{abstract}
From the Centre de Recherche des Cordeliers," University of Pierre and Marie Curie-Paris 6, UMRS 872, Paris, France; University of Paris-Descartes, ${ }^{\dagger}$ UMRS 872, Paris, France; INSERM U872, ${ }^{\ddagger}$ Paris, France; Laboratory of Molecular Oral Physiopathology, University of Paris-Diderot, UFR of Odontology, Paris, France; Reference Center for Oral and Facial Malformations, " Hospital Hotel-Dieu, AP-HP, Paris, France; and the Department of Basic Sciences," University of Antioquia, Medellin, Colombia
\end{abstract}

Signaling pathways that underlie postnatal dental and periodontal physiopathology are less studied than those of early tooth development. Members of the muscle segment homeobox gene (Msx) family encode homeoproteins that show functional redundancy during development and are known to be involved in epithelial-mesenchymal interactions that lead to crown morphogenesis and ameloblast cell differentiation. This study analyzed the MSX2 protein during mouse postnatal growth as well as in the adult. The analysis focused on enamel and periodontal defects and enamel proteins in Msx 2 -null mutant mice. In the epithelial lifecycle, the levels of MSX2 expression and enamel protein secretion were inversely related. $M s \times 2^{+/-}$mice showed increased amelogenin expression, enamel thickness, and rod size. Ms $x 2^{-/-}$mice displayed compound phenotypic characteristics of enamel defects, related to both enamel-specific gene mutations (amelogenin and enamelin) in isolated amelogenesis imperfecta, and cell-cell junction elements (laminin 5 and cytokeratin 5 ) in other syndromes. These effects were also related to ameloblast disappearance, which differed between incisors and molars. In $M s x 2^{-1-}$ roots, Malassez cells formed giant islands that overexpressed amelogenin and ameloblastin that grew over months. Aberrant expression of enamel proteins is proposed to underlie the regional osteopetrosis and hyperproduction of cellu- lar cementum. These enamel and periodontal phenotypes of Msx 2 mutants constitute the first case report of structural and signaling defects associated with enamel protein overexpression in a postnatal context. (Am J Pathol 2010, 177:2516-2526; DOI: 10.2353/ajpath.2010.091224)

Msx2 is a member of the Muscle segment homeobox gene (Msx) family, orthologous to the Msh gene of Drosophila. ${ }^{1}$ The mammalian Msx1 and Msx2 genes share highly conserved sequences. ${ }^{2}$ Their encoded homeoproteins show functional redundancy during development ${ }^{2,3}$. They act as transcriptional repressors which bind specific DNA sequences. ${ }^{4}$ In several early developmental processes, MSX2 signaling pathways have been elucidated. These-ones include: cranial suture closing, epithelial-mesenchymal interactions leading to crown morphogenesis, ${ }^{5}$ and ameloblast cell differentiation. ${ }^{6,7} \mathrm{~A}$ gain-of-function mutation in the Msx2 homeobox-gene sequence induces premature suture fusion (Boston-type 2 craniosynostosis; OMIM 604757). ${ }^{8}$ Conversely, a mutation leading to reduced MSX2 DNA-binding is associated with impaired suture closing in the parietal foramina (OMIM 168500). ${ }^{9}$ Another mutation, in the homeodomaincoding region, has been described in a family with amelogenesis imperfecta and impaired tooth eruption. ${ }^{10}$ Different mouse models (null mutant mice, ${ }^{5}$ transgenic mice bearing overexpression constructs ${ }^{11}$ and gene mutations $^{12,13}$ ) mimic the multiple craniofacial anomalies: precocious fusion of cranial bones, development of ectopic cranial bone, ${ }^{12}$ or contrarily, persistent calvaria foramina and dental defects, ${ }^{5}$ and reduction of bone ossification $^{13}$ and resorption. ${ }^{6}$ The present investigation focuses on the physiopathology of enamel and periodontal tissues in a knockin transgenic mouse model. ${ }^{6}$

MSX2 target-genes were first identified in osteoblasts. ${ }^{14}$ In vitro, the transcriptional repressor activity of

Accepted for publication July 13, 2010.

Address reprint requests to Muriel Molla, D.D.S, MPhil, Ph.D., Laboratoire de Physiopathologie Orale Moléculaire, Centre de Recherche des Cordeliers, INSERM, UMRS 872, Université Paris-Diderot, Equipe 5, Esc. E-2ème étage, 15-21 rue de l'école de Médecine, F-75270 Paris Cedex 06, France. E-mail: murielmolla@gmail.com. 
MSX2 was shown to be mediated through interactions with distinct transcriptional factors such as DLX homeoproteins for osteocalcin ${ }^{15}$ and the CCAAT/enhancerbinding protein $\alpha(\mathrm{C} / \mathrm{EBP} \alpha)$ for amelogenin. ${ }^{16}$ In osteoblasts, MSX2 exerts either positive or negative effects on osteocalcin transcriptional activity depending on the stage of osteoblast differentiation and thus diverse MSX2 transcriptional partners. ${ }^{17-19}$ Therefore, the impact of MSX2 depends on the cellular circumstances. Recent in vivo studies addressed the role of MSX2 in late postnatal growth and adult homeostasis. ${ }^{3,6}$ These studies demonstrated additional roles for MSX2 in physiological regulation of postnatal mineralized tissue formation, modeling and homeostasis. In addition to enamel and dentin dysplasia and altered root formation, these mutant mice exhibit regional osteopetrosis resulting from site-specific down-regulation of RANKL expression in the alveolar bone ${ }^{6}$ which mechanisms are not understood.

In addition to osteocalcin and amelogenin, other enamel matrix proteins constitute candidate MSX2 targets. Their aberrant expression is hypothesized here to underlie the broad dento-alveolar spectrum of alterations associated with Msx2 mutation. Indeed, enamel proteins could play a dual role in mineralized tissues, acting both as a structural scaffold for amelogenesis and as signaling molecules for mineralized tissue formation and resorption. Amelogenin proteins self-assemble into nanospheres and coils which serve as an enamel scaffold. ${ }^{20}$ These transient self-assemblies run throughout the enamel layer and guide apatite crystal formation and growth. ${ }^{21,22}$ Amelogenin null mice show a significant reduction of enamel thickness which is in addition devoid of prismatic pattern. ${ }^{23}$ Two other enamel proteins, enamelin and ameloblastin, also cooperate in enamel morphogenesis, as shown by their extracellular distribution in forming enamel and the phenotype of their respective null mutants. ${ }^{24,25}$ On the other hand, dentin sialophosphoprotein (DSPP) is transiently expressed in presecretion-stage ameloblasts and initiates enamel biomineralization. ${ }^{26}$ Therefore, these four enamel proteins (amelogenin, enamelin, amelobastin, and DSPP) cooperate in the control of biomineralization events and are essential for enamel morphogenesis. Isolated amelogenesis imperfecta, which comprises a family of hereditary diseases affecting enamel structure, including hypoplastic, hypomaturation ,and hypomineralization types, is associated with mutation of the corresponding genes in humans. ${ }^{27}$

Besides their role as structural proteins, amelogenin and ameloblastin isoforms are proposed to play a role in cell signaling. ${ }^{28}$ Amelogenin peptides were shown to induce bone-cell differentiation via Runx-2 pathway activation in vivo and in vitro. ${ }^{29,30}$ Amelogenin null mutants show regional hyperesorption mediated by activation of RANKLRANK pathway. ${ }^{31,32}$ Interestingly, the amelogenin gene was one of the first identified MSX2 target-genes for which transcriptional repression was deciphered at the molecular level. ${ }^{33}$ While this in vitro MSX2 action has been well documented, no in vivo studies have been performed regarding the relationship between MSX2 expression and enamel proteins.
Based on MSX2 transcriptional repression of the amelogenin gene established in vitro and the potential functions of enamel proteins, the purpose of this study was to scrutinize enamel proteins in vivo in Msx2 mutants mice. Postnatal phenotypes were compared in $\mathrm{Ms} 2^{+/+}$ (wild type), Msx2 $2^{+-}$(heterozygous) and $\mathrm{Msx}^{-1-}$ (homozygous) mice. MSX2 and enamel proteins were analyzed in the dental epithelium throughout its life cycle: enamel organ during amelogenesis, Hertwig's root sheath during root formation, and Malassez remnants in the adult periodontium. A inverse relationship was observed between Msx2 gene dosage and expression levels of enamel-related genes in the dental epithelium. Our data revealed the existence of a beneficial impact of loss of a single Msx2 allele on enamel formation in $\mathrm{Ms} \mathrm{2}^{+/-}$ mice which was not previously described. In $\mathrm{Ms} 2^{-1-}$ mice, the data suggest a parallel relationship between epithelial amelogenin and ameloblastin levels and alveolar bone and cementum homeostasis.

\section{Materials and Methods}

\section{Expression Analysis in Knockin Msx2/lacZ Transgenic Mice}

Knockin mice were produced by insertion of the bacterial lacZ gene within the Msx2 gene, replacing the coding sequence. ${ }^{6}$ Heterozygous males and females were mated using a CD1 Swiss genetic background. Their litters were

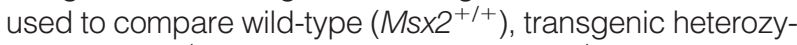

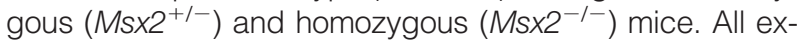
periments were performed in accordance with the French National Consultative Bioethics Committee for Health and Life Science, following the ethical guidelines for animal care. All experiments were performed by staff trained to conduct in vivo studies.

\section{RNA Extraction and RT-qPCR}

Twenty-one 3-month-old mice were used for each group $\left(\mathrm{Ms} \mathrm{2}^{+/+}, \mathrm{Ms} \times 2^{+/-}\right.$, and $\left.\mathrm{Ms} \times 2^{-/-}\right)$. Half mandibles were removed, quickly frozen in liquid nitrogen and ground up. Dental epithelial cells of the continuously erupting incisor and alveolar bone were microdissected out under a stereomicroscope. The cervical loops were excised to avoid mesenchymal contamination. Three pools including three different animals per pool were generated. Total RNA was extracted using a Trizol reagent kit (Invitrogen, Cergy-Pontoise, France) according to the manufacturer's protocol. After total RNA quantification, equal amounts of RNA $(1 \mu \mathrm{g})$ were transcribed into cDNA using SuperScript II RNase H reverse transcriptase (Invitrogen) with oligo-dT and hexanucleotide random primers. Gene expression levels were determined by real-time PCR using specific primers (Table 1). Optimal conditions and CDNA dilutions were determined for each gene. q-PCR experiments were performed with a Roche LightCycler in triplicate using FastStart DNA Master SYBR Green I (Roche, Neuilly-sur-Seine, France). 
Table 1. Primer Sequences and PCR Conditions Used for RT-qPCR Analysis

\begin{tabular}{|c|c|c|c|}
\hline Gene & Oligonucleotides & Size (bp) & $\operatorname{Tm}\left({ }^{\circ} \mathrm{C}\right)$ \\
\hline \multicolumn{4}{|l|}{ Amelogenin } \\
\hline P1 & 5'-GGATCAAGCATCCCTGAGTTTCAAAC-3' & 370 & 60 \\
\hline P2 & $5^{\prime}$-ATCATTGGTTGCTGGGGGATCAC-3' & & \\
\hline \multicolumn{4}{|c|}{ 5 - ATCATIGGITGCIGGGGGACAC - 3} \\
\hline P1 & 5'-САСТTACTATCCTTCCGCAG-3' & 181 & 58 \\
\hline P2 & $5^{\prime}$-GTGCTGACACTTAGACTTGC-3' & & \\
\hline \multicolumn{4}{|c|}{ 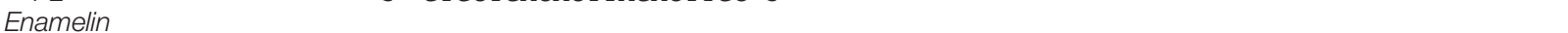 } \\
\hline P1 & 5'-TCGGAGGGATGTTCTGAAAC-3' & 232 & 58 \\
\hline P2 & 5'-AGGACTTTCAGTGGGTGTGG-3' & & \\
\hline \multicolumn{4}{|c|}{ 5 -AGGALI"ICAGIGGGIGIGG-3 } \\
\hline P1 & 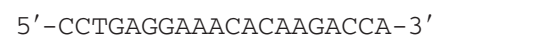 & 278 & 60 \\
\hline P2 & 5'-AGTTGATAGGGAAGGGCAGA - 3' & & \\
\hline \multicolumn{4}{|c|}{ 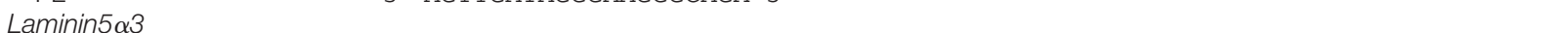 } \\
\hline P1 & 5'-GGGTGTGACCAAAAAGTGCT-3' & 206 & 58 \\
\hline P2 & 5'-CATCTTCCAGGGTGACCAGT-3' & & \\
\hline \multicolumn{4}{|c|}{ כ -CATLIILCAGGGIGALCAGITS } \\
\hline P1 & 5'-TCAAGAAGCAGTGTGCCAAC-3' & 217 & 58 \\
\hline P2 & 5'-TCCAGCAGCTTCCTGTAGGT-3' & & \\
\hline \multicolumn{4}{|c|}{ 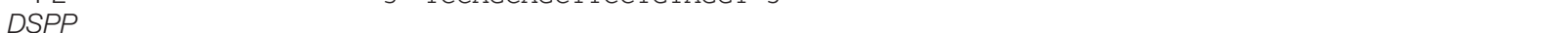 } \\
\hline P1 & $5^{\prime}$-ACAAGAGTGGGACCCTGTTT-3' & 399 & 58 \\
\hline P2 & 5' -TACAGTGTGGGCGTTACAAC-3' & & \\
\hline
\end{tabular}

\section{Scanning Electron Microscopy Analysis of Mandible Incisor and Molar Enamel}

Six mandibles from 3-month-old $\mathrm{Ms} \mathrm{2}^{+/+}, \mathrm{Ms} \mathrm{2}^{+/-}$and Ms $\times 2^{-1-}$ mice were fixed for 24 hours in $4 \%$ paraformaldehyde in PBS, pH 7.4. Samples were then cut along the frontal axis into two fragments before the first molar by using a rotating diamond wheel. Previous microscanner analysis was used to validate the cutting axis (perpendicular to incisor axis). Dehydration was performed using increasing concentrations of ethanol for 24 to 48 hours each at $4^{\circ} \mathrm{C}$. Each fragment was embedded in calibrated cylinders with clear polyester resin. The first fragment, corresponding to the buccal part of the incisor, was ground through bone emergence using optically controlled monitoring. The second fragment was ground until the mesial surface of the first molar appeared. Sample surfaces were polished with sandpaper of successively decreasing grits. Conditioning of the enamel surface was achieved by etching with 37\% phosphoric acid for 10 seconds. Each sample was coated with palladium-gold in a vacuum evaporator and observed with a scanning electron microscope (JSM-6400, JEOL, Tokyo) at $10 \mathrm{kV}$. The morphology of incisor was used as a criteria to calibrate the section planes based on the established $\mu \mathrm{CT}$ landmarks.

\section{Sample Preparation for Histomorphology, in Situ Hybridization, and Immunolabeling}

$M s \times 2^{+/+}, M_{s \times 2}{ }^{+/-}, M s \times 2^{-1-}$ mouse mandibles (four animals for each group, at ages 1, 2, 3, 6, 12, and 24 weeks) were dissected out, fixed by immersion in $4 \%$ paraformaldehyde for 24 hours at $4^{\circ} \mathrm{C}$, and rinsed in PBS. Half of the samples were decalcified at $4^{\circ} \mathrm{C}$ with EDTA (4\%) for 4 to 64 weeks, depending on mouse age. Right halfmandibles were rinsed, dehydrated and embedded in paraffin for sectioning. Sections of $7 \mu \mathrm{m}$ were deparaf- finized and rehydrated before being stained with hematoxylin and eosin for histological analysis or subjected to immunohistology. For the left half-mandibles, $10-\mu \mathrm{m}$ cryostat sections without decalcification were made with a Leica CM 3050S Microtome (Leica, Rueil-Malmaison, France) and deposited onto poly-L-lysine (Sigma)-coated slides, dehydrated in a graded series of ethanol, and stored at $-20^{\circ} \mathrm{C}$.

\section{In Situ Hybridization}

Amelogenin sense and antisense RNA probes were prepared from full-length cDNA (covering exons 2-3-5-6-7; see Bonass et $\mathrm{al}^{34}$ ), subcloned into a Bluescript plasmid and linearized with Xhol or Pstl endonucleases.

For radioactive in situ hybridization, $\left[{ }^{35}\right.$ S]UTP-labeled single-stranded antisense and sense probes were synthesized using T7 and T3 RNA polymerase, respectively (Boehringer, Meylan, France). ${ }^{34}$ For nonradioactive in situ hybridization, the same probes were labeled with UTPdigoxigenin (Roche, France).

Radioactive in situ hybridization was performed as previously described by Hotton et $\mathrm{al}^{35}$ on non-decalcified samples. Briefly, cryostat sections were pretreated with proteinase K (Sigma), hybridized with $20 \mu$ l of labeled probes containing $60,000 \mathrm{cpm} / \mu \mathrm{l}$ in a humid chamber overnight at $50^{\circ} \mathrm{C}$, and washed under high-stringency conditions. The slides were dipped into NTB2 autoradiographic emulsion (Kodak, Paris, France) and exposed from 2 to 4 weeks at $4^{\circ} \mathrm{C}$. After developing the film, the sections were stained with hematoxylin, dehydrated, and mounted under a coverslip. The sections were examined and photographed using a DRMB photomicroscope (Leica, France) under bright- and dark-field illumination.

For nonradioactive in situ hybridization, sections were deparaffinized, dehydrated, and hybridized overnight with $50 \mu \mathrm{l}$ of labeled probe $(1 \mathrm{ng} / \mu \mathrm{l})$ in a dark, humid chamber. The reaction was revealed by immu- 
nocytochemistry using an anti-digoxigenin alkaline phosphatase-conjugated polyclonal antibody (Vector NovaRED; Abscyss, Paris, France). The sections were then stained with Mayer's hematoxylin and dehydrated before being mounted under a coverslip and photographed.

\section{Immunohistochemistry}

Deparaffined and rehydrated sections were incubated for 30 minutes in $3 \% \mathrm{H}_{2} \mathrm{O}_{2} /$ PBS to quench endogenous peroxidase activity, and then rinsed for 10 minutes in PBS. Nonspecific protein binding was blocked by incubation for 30 minutes in $10 \%$ normal goat serum and $1 \%$ bovine serum albumin in PBS. Specimens were incubated for 1 hour at room temperature in a humidified chamber with a polyclonal rabbit anti-mouse $\beta$-galactosidase antibody (Genetex), anti-amelogenin (generous gift of Pr. S. Sasaki, Tokyo Medical and Dental University, Department of Biochemistry, diluted at 1:1000) and anti-ameloblastin (generous gift of Pr. Tilmann Wurtz, Centre de Recherche des Cordeliers, Paris, France; diluted at 1:1400). Sections were then washed extensively three times in PBS at room temperature before treatment for 30 minutes at room temperature with the secondary biotin-labeled goat anti-rabbit IgG antibody (StrAviGen Multilink kit, Biogenex, UK) for $\beta$-galactosidase, and with horseradish peroxidase goat anti-rabbit IgG antibody (DAKO) for
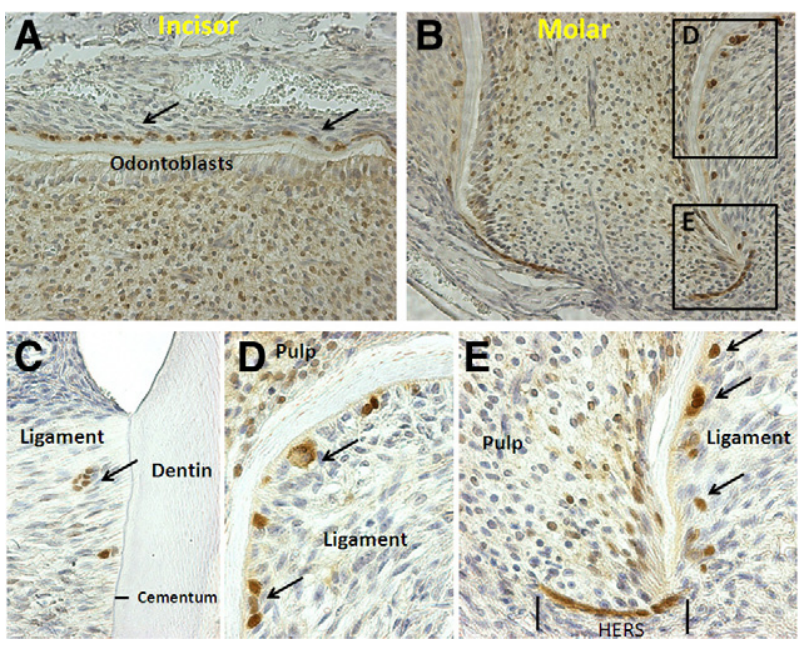

Figure 2. Immunolocalization of $\beta$-galactosidase protein in $M s \times 2$ knock-in heterozygous mouse root. Epithelial life cycle is followed in an incisor (A) and first molar (B-E). Different cells are recognized according to their morphology and position. At postnatal week 2, MSX2 expression is evident in odontoblasts, pulp cells, ERM (arrows), and Hertwig epithelial root sheath (between the vertical black lines). HERS, Hertwig epithelial root sheath). Black rectangles in $\mathbf{B}$ are shown enlarged in $\mathbf{D}$ and $\mathbf{E}$

amelogenin and ameloblastin. Subsequently, sections were incubated for 30 minutes at room temperature with peroxidase linked to avidin (Vectastain ABC kit, Vector Laboratories, Burlingame, CA) for $\beta$-galactosidase, and
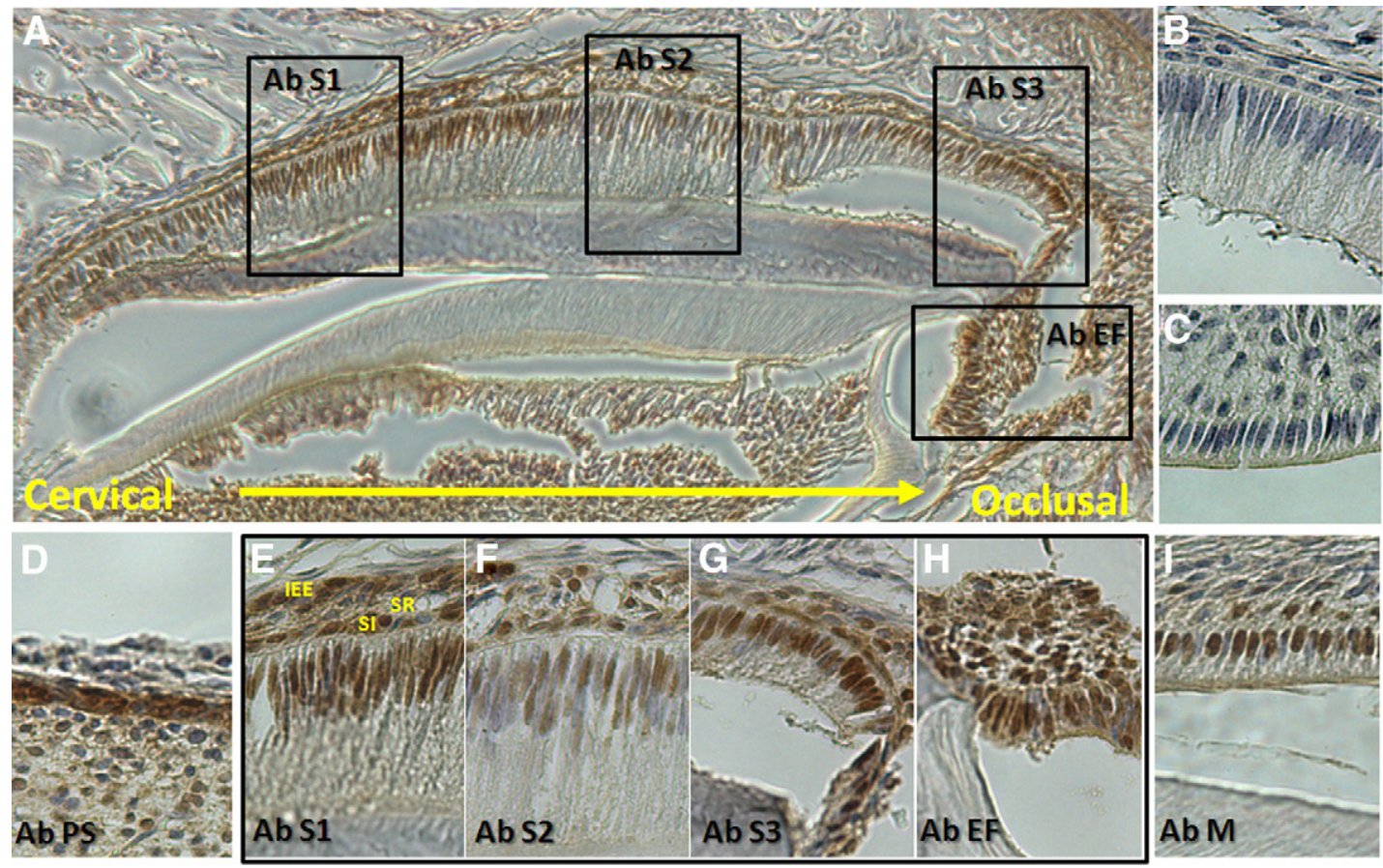

Figure 1. Immunolocalization of $\beta$-galactosidase protein in Msx 2 knock-in heterozygous mutant mouse molar crown. MSX2 expression is shown labeled in brown at $1(\mathbf{A}, \mathbf{D}, \mathbf{H})$ and $2(\mathbf{B}, \mathbf{C}, \mathbf{I})$ postnatal weeks. A represents a sagittal view of a molar, with the cervical area on the left and the occlusal part on the right. Black rectangles are enlarged in $\mathbf{E}-\mathbf{H}$. Ameloblast stage was determined according to their morphology and location in the molar crown. At 1 week, most ameloblasts are at the secretion stage while at 2 weeks, most of the ameloblasts are at the maturation stage. Ab PS, presecretion stage ameloblasts; Ab S, secretion stage ameloblasts in 3 areas: Ab S1 corresponds to the cervical part of the crown where enamel thickness is reduced, Ab S2 corresponds to the middle part of the crown where enamel thickness is greatest, and $\mathrm{Ab}$ S3 corresponds to the cusp area where enamel thickness decreases. Ab EF, ameloblast facing the enamel-free area; Ab M, maturation stage ameloblasts; IEE, inner enamel epithelium; SR, stellate reticulum; SI, stratum intermedium. Strong labeling is noted in presecretion stage ameloblasts (D), maturation stage ameloblasts (I) and in ameloblasts facing the enamel-free area in the occlusal crown $(\mathbf{H})$. In secretion stage ameloblasts, labeling decreases with enamel thickness: at the middle region of the crown, corresponding to the thickest enamel layer, brown labeling is less intense (Ab S2, F); at the cervical and occlusal parts of the crown where the enamel layer is thinner, labeling is stronger ( $\mathrm{Ab} \mathrm{S1}$ and Ab S3, E-G). Experiments without primary antibody are controls (B and $\mathbf{C})$. 
with a NovaRED kit (Vector Laboratories) for amelogenin and ameloblastin. After rinsing in PBS, the immunoreactivity was visualized by development for 2 to 10 minutes with $0.1 \%$ 3,3-diaminobenzidine and $0.02 \% \mathrm{H}_{2} \mathrm{O}_{2}$ (DAB substrate kit, Vector Laboratories). For $\beta$-galactosidase analysis, sections were counterstained with Mayer's hematoxylin, mounted with permanent mounting medium (XAM, BDH Laboratory, England) and examined by light microscopy. Amelogenin and ameloblastin labeling samples were not counterstained but mounted with aqueous medium (Labonord, Lille). A positive control was performed on untreated mouse teeth and a negative control on mouse oral mucosa. A further negative control experiment that omitted primary antibody was also performed on mouse tooth sections.

\section{Results}

\section{MSX2 Expression in Odontogenic Cells}

MSX2 expression was analyzed during the first 4 postnatal months in the mandibular first molar of $\mathrm{Ms} 2^{+/-}$mice by using $\beta$-galactosidase immunostaining. Developmental stages of ameloblasts have been identified based on their cell morphology. Presecretion stage ameloblasts are short, and are adjoining differentiated mesenchymal cells forming predentin and dentin with no enamel deposition. Secretion stage ameloblast are polygonal and elongated with a large basal nucleus and distal Tomes processes. Enamel deposition is visible. Maturation stage ameloblasts do not possess Tomes process, become abruptly much shorter and reduced in size. The enamel thickness is stable.

During amelogenesis (Figure 1), MSX2 expression was stronger in presecretion-stage ameloblasts (Ab PS) (Figure 1D) and in mature, postsecretion-stage ameloblasts (Ab M) (Figure 1I) than in secretion-stage ameloblasts (Ab S) (Figure 1, A, D-H). Figure 1, B and C, show controls without primary antibody. Ab S1, S2, and S3 represent secretion-stage ameloblasts adjoining enamel area with different thicknesses, in the cervical part, the middle to upper part, and the occlusal part of the molar crown, respectively. In secretion-stage ameloblasts, MSX2 expression appeared to be less intense in areas of greater enamel thickness ( $A b$ S2 versus Ab S1 and Ab S3). Strong MSX2 expression was observed in zones of mouse molar corresponding to enamel-free areas ( $A b$ EF). MSX2 expression was also detected in forming and adult periodontium. During root elongation, MSX2 was expressed in Hertwig epithelial root sheath and, after its disruption, in epithelial rests of Malassez (ERM) (Figure 2, A-E). Epithelial rests of Malassez cells continued to express significant levels of Msx2 in adults. Quantitative analysis of Msx2 transcripts in ameloblasts (Figure 3) validated the absence of Msx2 transcripts in Ms $\times 2^{-1-}$ mice and a half reduction in $M s \times 2^{+/-}$heterozygous mice

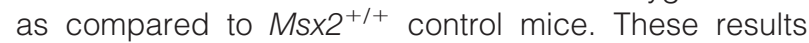
indicate the occurrence of a haploinsufficiency phenomenon in heterozygous mice.

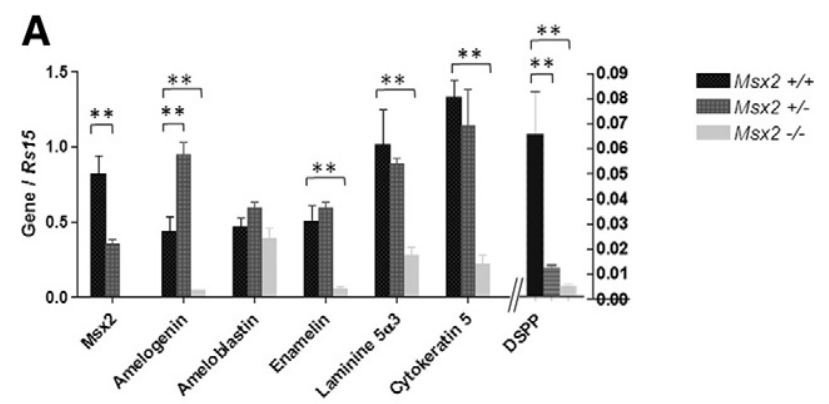

B

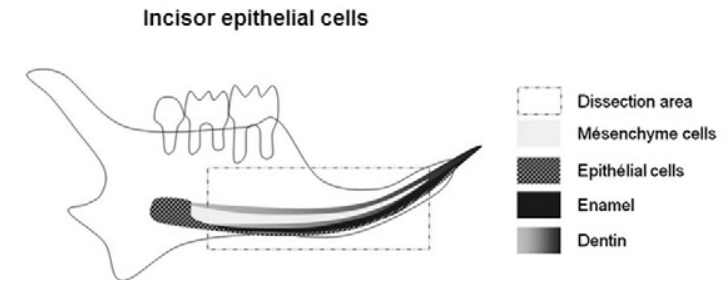

Figure 3. Quantitative RT-PCR analysis of $M s x 2$ (A) and enamel mRNA isolated from microdissected incisor epithelial cells in $M s x 2^{+/+}, M s x 2^{+/-}$ and $M s \times 2^{-1-} 12$-week-old mice (B). Each level of mRNA expression is normalized with stable ribosomal protein RS15 mRNA. The histograms show the mean \pm SEM of data obtained from nine mandibles for each group (in triplicate). Significance was evaluated using the Mann-Whitney test $\left({ }^{*} P<\right.$ $\left.0.05,{ }^{* *} P<0005\right)$.

\section{Msx2 Dosage Regulates Enamel Proteins}

To estimate the variation in the levels of the mRNAs encoding enamel proteins in relationship to MSX2 expression levels, dental epithelium was microdissected from mouse mandible incisor and total mRNA was isolated. To analyze mRNA expression in a homogenous population of ameloblasts, the cervical loop was carefully removed. Levels of mRNA encoding enamelin, ameloblastin, amelogenin, laminin $5 \alpha 3$, cytokeratin 5 , and DSPP were measured by RT-qPCR in $\mathrm{Ms} \mathrm{2}^{-1-}, \mathrm{Ms} \mathrm{2}^{+/-}$ and $M s \times 2^{+/+}$mice. The amelogenin primers were chosen to amplify the M180 major transcript. As expected, sequencing revealed that the amplified amelogenin cDNA contained exons 2, 3, 5, and 6. In Ms $\times 2^{+1-}$ heterozygous mice, only the modulation of amelogenin expression was found to be statistically significant among all enamel protein-encoding genes. As shown in Figure 3, amelogenin expression increased twofold in heterozygous mice as compared to wild type. In contrast, Dspp transcript expression was significantly reduced in heterozygous mice. In Ms $\times 2^{-1-}$ null mice, the amounts of amelogenin, enamelin, laminin $5 \alpha 3$, cytokeratin 5 , and Dspp mRNA were all significantly decreased, whereas no significant variation of ameloblastin mRNA was observed.

To localize amelogenin mRNA expression in secretionstage ameloblasts, in situ hybridization was performed on incisor sections of 21-day-old mouse mandible (Figure 4, $\mathrm{A}$ and $\mathrm{B}$ ). mRNA labeling was stronger in $\mathrm{Ms} 2^{+/-}$(Figure 4, $\mathrm{C}$ and $\mathrm{D}$ ) than in $\mathrm{Ms} 2^{+/+}$mice (Figure $4, \mathrm{~A}$ and $\mathrm{B}$ ). Scattered ectopic mRNA was observed in stratum intermedium cells. In Msx2 null mice, no significant hybridization signal was detected in incisor (Figure 4E) as expected because of the complete disappearance of ameloblasts. Detailed analysis in molar showed some areas with few ameloblasts corresponding to irregular 


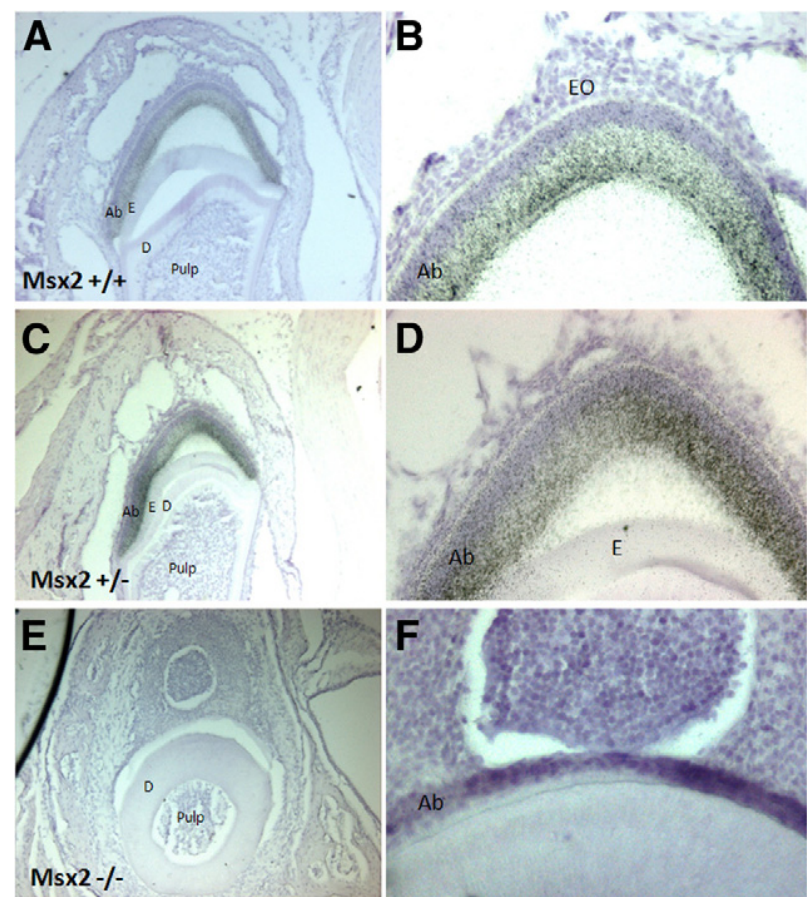

Figure 4. Radioactive in situ hybridization of amelogenin mRNA in $M s x 2^{+/+}, M s x 2^{+/-}$, and $M s x 2^{-/-}$mouse incisors at 21 postnatal days. In Ms $x 2^{+1+}$ mice, amelogenin expression is located in the cell body of secretion-stage ameloblasts (A and $\mathbf{B}$ ). In $M s \times 2^{+/-}$mutant mice, labeling is stronger (C and D). In $M s \times 2^{-/-}$mutant mice, amelogenin labeling was absent, as expected (E and $\mathbf{F})$. Ameloblasts are not polarized or rounded $(\mathbf{F})$. $\mathrm{Ab}$, ameloblast; E, enamel; D, dentin; EO, enamel organ.

amelogenin labeling (Figure 4F). Indeed, some polarized ameloblasts were present in the cervical area, whereas in the most occlusal part, epithelial cells in contact with dentin showed no evidence of ameloblast polygonal structure and organization, but rather a shorter and round morphology (Figure 4F).

Histological studies of $M s \times 2^{-1-}$ mouse mandibular molars showed anomalies of root-tissue development inducing root dysmorphology, with a gradient of severity from the third to the first molar. In the first molar the root dentin was formed and no obvious anomaly was observed until day 10 (data not shown). The second molar exhibited in some areas a total absence of root dentin formation and a massive cellular cementum-like structure (hypercementosis). Some ectopic mineralized tissue was seen in the pulp chamber. The third molar showed a complete root shape and structural disorganization. Moreover in all molars, hypertrophy of epithelial cells was observed at several sites. The first major site was localized adjacent to the crown-root junction and the second was more diffuse. These cells comprised clusters of only a few cells termed the ERM in wild-type mice (Figure 5, G and $\mathrm{H}$ ). This analysis revealed three different sizes of cluster in Msx2 null mutant mice: small ones composed of two or three cells (as in wild type), medium ones composed of five or six cells, and giant ones composed of more than 10 cells. The bigger these islands, the more extracellular matrix was present and the more the cells were enlarged. Histomorphometric analysis was performed with image analysis software to calculate the area occupied by and the number of epithelial cluster cells along the roots (Figure $5 \mathrm{I}$ ). In $\mathrm{Ms} \mathrm{2}^{-1-}$ mice, these clusters appeared less numerous but much larger than in wild-type mice and their size appeared to increase with age (4.6-fold at 2 postnatal weeks, Figure 5, A-C; 14-fold at 4 postnatal weeks; 30-fold at 8 postnatal weeks, Figure 5, D-F). At 2 to 6 months most of these clusters were entrapped in the cellular cementum (Figure 5, D-F). In addition, in situ hybridization and immunolabeling showed that they overexpressed both amelogenin and ameloblastin (Figure 6, B-E) compared to wild type (Figure 6A).

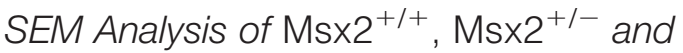 Msx2 ${ }^{-1-}$ Mouse Enamel}

For comparison, the corresponding areas of mature enamel in $\mathrm{Ms} 2^{+1+}, \mathrm{Ms} \times 2^{+/-}$and $\mathrm{Ms}^{+2^{-1-}}$ mouse mandible incisors are shown in Figure 7. The thickness of the enamel layer differed between the three mouse genotypes. The enamel layer of the Msx2 $2^{-1-}$ null mouse was markedly reduced (2.6-fold) (Figure 7E), whereas the thickness of the enamel layer in the heterozygous mouse was increased 1.3-fold (Figure 7C). In addition to this thickness modification, the enamel had a different structural pattern in the different genotypes. In the Msx2 null mouse, the enamel was reduced to a thin layer, homogeneous in structure with cracks inside and lacking its usual prismatic appearance (Figure 7F). Heterozygous mice showed a regular prismatic structure similar to normal enamel with rods cut in alternating sagittal and transversal orientations (Figure 7C). Yet, some differences were noticed. The external prismatic enamel layer, in which all prisms were cut transversally, was much larger in the heterozygous mouse tooth than in the wild-type mouse tooth (increasing twofold) (Figure 7, A-D). Most of the enamel body consists of rod and inter-rod enamel. Rods present a classical keyhole shape when they are transversally cut. Each rod is separated with inter-rod enamel connecting to the rod on one side. Ms $\times 2^{+/-}$ heterozygous mice exhibited much larger prisms (2.7 \pm $0.2 \mu \mathrm{m}$ in width in Msx2 ${ }^{+/-}$mice versus $1.9 \pm 0.2 \mu \mathrm{m}$ in $\mathrm{Ms}^{2} 2^{+/+}$mice) (Figure 7, $\mathrm{G}$ and $\mathrm{H}$ ).

\section{Discussion}

Disruption of one $\left(\mathrm{Ms} \times 2^{+/-}\right)$or two $\left(\mathrm{Ms} 2^{-1-}\right)$ copies of the Msx2 gene led to specific abnormalities in teeth. In the $M s \times 2^{+1-}$ mouse, both enamel thickness and amelogenin expression in ameloblasts were increased. In Ms $\times 2^{-1-}$ mice, epithelial cells showed divergent alterations in the crown and root: reduced expression of enamel matrix proteins in the crown was associated with the disappearance of ameloblasts, whereas in the root, epithelial Malassez cells accumulated progressively throughout postnatal growth and in adult periodontium (the calculated area of the ERM was increased 4.6-fold at 2 postnatal weeks and 30fold at 8 postnatal weeks). The latter cells formed hypertrophic islands (showing increased width and numbers of 

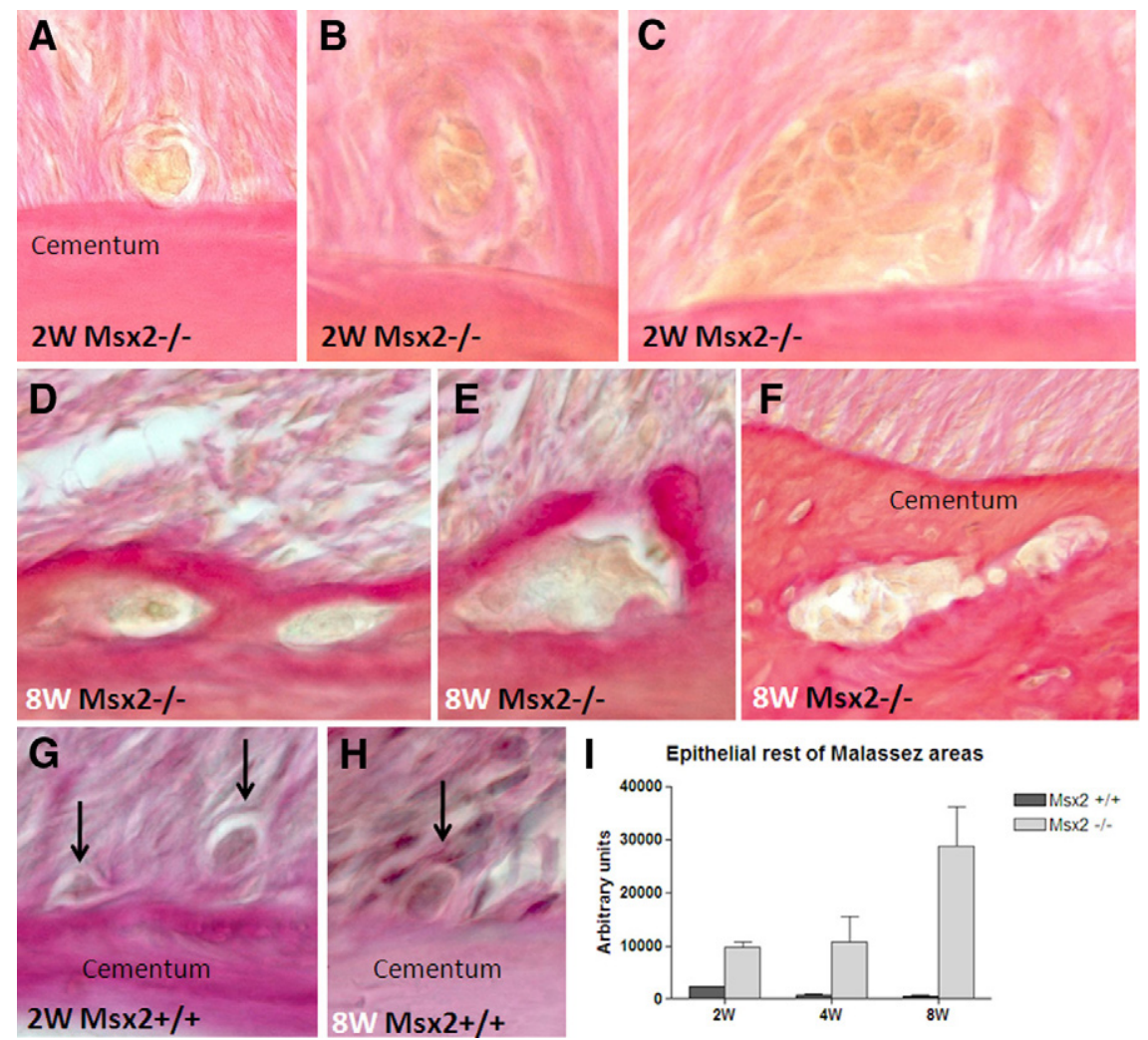

西

Epithelial rest of Malassez areas

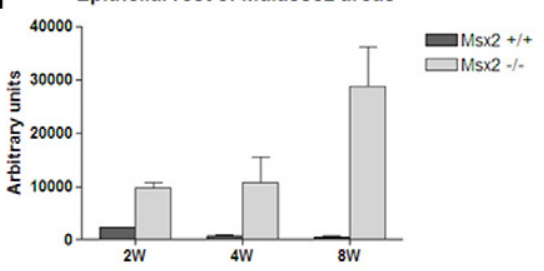

Figure 5. Analysis of epithelial rest of Malassez in $M s x 2^{+1+}$ and $M s x 2^{-1-}$ mouse molars. Pictures represent epithelial cells in the periodontal ligament along root, in contact to cementum. Epithelial clusters were analyzed at 2 weeks (AC), 4 weeks (not shown), and 8 weeks (D-F) in Ms $\times 2^{+/-}$mice versus controls (2 weeks, G; 8 weeks, $\mathbf{H})$. Surface areas were measured on four different first mandibular molars from $M s \times 2^{+/+}$ and $M s \times 2^{-1-}$ mice along the root length. These measurements were performed at 2, 4, and 8 postnatal weeks. In Msx2 null-mutant mice, three types of clusters could be observed: $\mathbf{A}$, a small cluster with only a few cells, similar to the clusters in wild-type mice; $\mathbf{B}$, medium-sized with 5- 6 cells; and $\mathbf{C}$, a large cluster including more than 10 cells. At 8 postnatal weeks, most of the cell clusters are included in cementum (D-F). In wild-type mice, epithelial rest of Malassez are present all along the root and composed of one or very few cells at 2 weeks (G, arrows), 4 weeks (not shown), and 8 weeks (H, arrow). Image analysis software (Image J) was used to measure epithelial cell areas (I). ERM areas increased from 2 weeks (ratio Msx $2^{-1-}$ versus Msx $2^{+/+}=4$ ) to 4 weeks (ratio $=14$ ) to 8 weeks $($ ratio $=30)$. cells) that overexpressed enamel proteins at both the mRNA and protein levels.

\section{MSX2-A Regulator of Enamel Architecture via Transcriptional Control of Amelogenin Levels}

The amelogenin promoter harbors five response elements containing canonical TAATT-binding motifs for
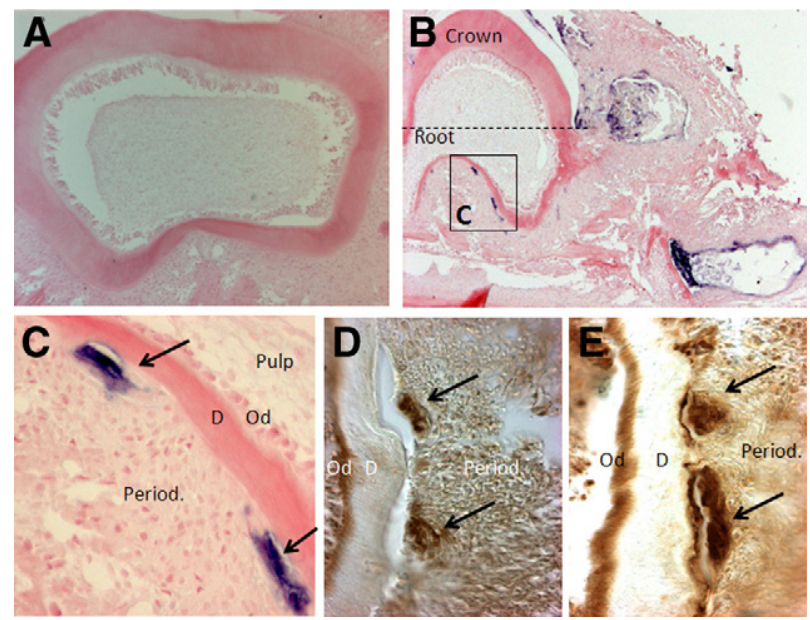

Figure 6. Amelogenin and ameloblastin expression in $M s \times 2^{+/+}(\mathbf{A})$ and $M s \times 2^{-/-}(\mathbf{B}-\mathbf{E})$ mice at 3 postnatal weeks. A-C: Nonradioactive in situ hybridization to amelogenin mRNA reveals a significant increase in giant ERM in Msx2-null mutants (arrows). D confirms increased amelogenin protein expression by immunoperoxidase staining (arrows). E shows significant ameloblastin protein levels by immunoperoxidase staining in the same ERM (arrows). Such intensity of amelogenin and ameloblastin immunolabeling is not observed in wild-type mice (data not shown); D, dentin; Od, odontoblast; Period., periodontium. both MSX and DLX homeoproteins. ${ }^{36}$ Four DLX genes are expressed in ameloblasts. ${ }^{36,37}$ In vitro, both positive and negative DLX effects on amelogenin promoter activity were shown to depend on the identified homeodomain-binding sites. In contrast, MSX2 behaves as a repressor of the amelogenin promoter, ${ }^{33,38}$ in part by antagonizing $\mathrm{C} / \mathrm{EBP} \alpha{ }^{16}$ These in vitro findings motivated the present investigation. Here, the observed increased level of amelogenin expression in $M s \times 2^{+/-}$ameloblasts is interpreted as resulting from reduced transcriptional repressor activity of MSX2. Indeed, Msx2 RNA levels mir-

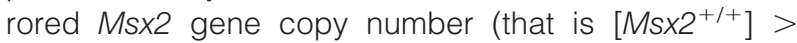

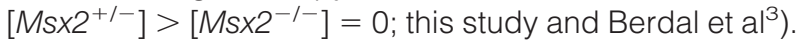
Amelogenin mRNA was increased twofold in $M s \times 2^{+/-}$ mice compared to wild-type mice. For other molecular species, such as matrix (ameloblastin, enamelin), cytoskeletal (cytokeratin 5) and cell adhesion (laminin 5 $\alpha 3$ ) proteins, no significant differences were found between the heterozygous and wild-type mice.

On the other hand, we found that the cells with the highest levels of MSX2 expression were not actively forming enamel matrix or producing significant amounts of amelogenin. These cells include presecretion- and maturation-stage ameloblasts, ${ }^{39}$ enamel-free zone ameloblasts ${ }^{40}$ and, even more strikingly, the cells of the Hertwig root sheath ${ }^{41}$ and ERM. ${ }^{42}$ This suggests that MSX2 downregulation is a prerequisite for significant enamel deposition, exclusively realized by secretion-stage ameloblasts. Indeed, the present data establish a link between MSX2-controlled amelogenin levels and enamel morphogenesis (regional enamel thickness and rod/inter-rod proportion). An increase of approximately 1.3-fold in 


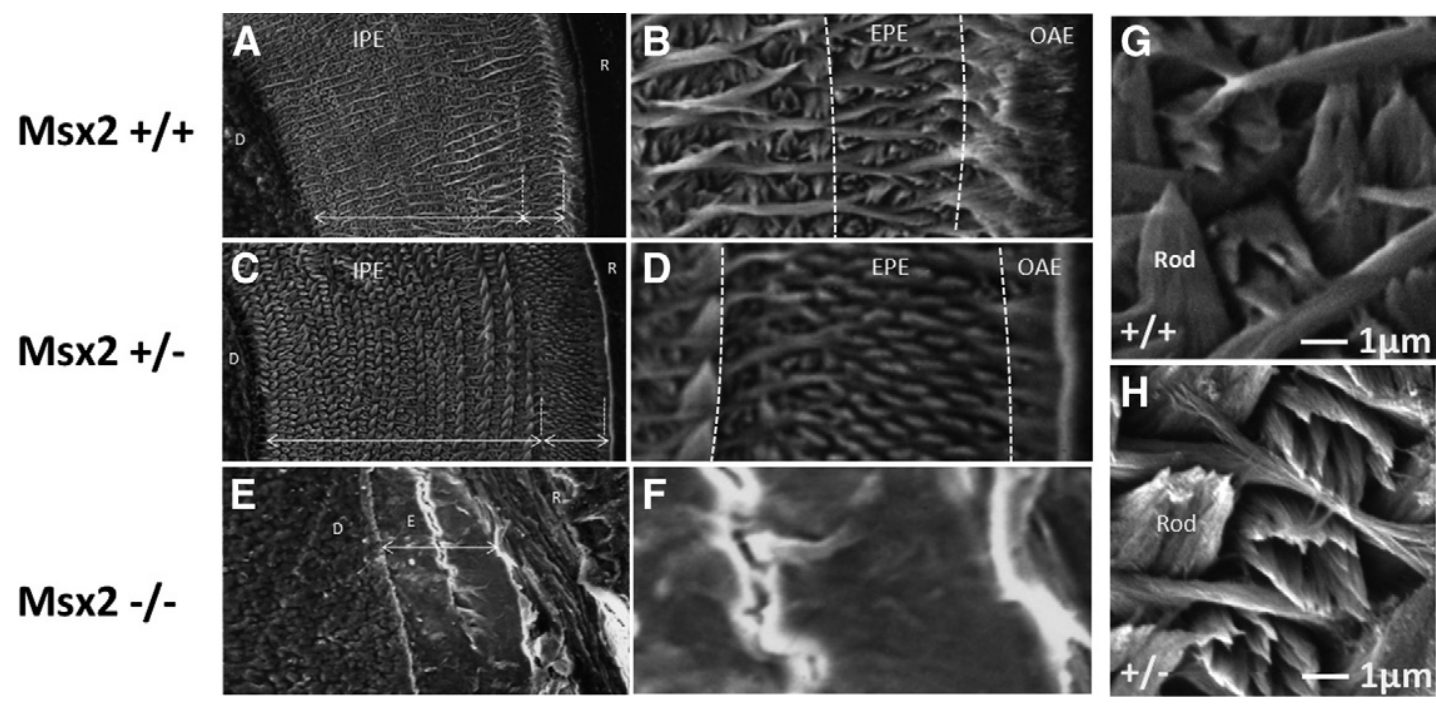

Figure 7. Scanning electron microscopy of transverse sections of mature enamel incisor (sagittal view) from $M s \times 2^{+/+}, M s \times 2^{+/-}$, and $M s \times 2^{-/-}$mice at 3 postnatal months. The accuracy of each section location was established by the size and shape of incisor enamel and dentin, based on a preliminary study using microCT-3D reconstruction (data not shown). Compared to the situation in wild type (A), enamel thickness is higher $(\times 1.3)$ in $M s x 2^{+/-}$mice $(\mathbf{C})$ and lower in $M s x 2^{-/-}$mice $(\times 0.38)(\mathbf{E})$. The most significant difference between $M s \times 2^{+/+}(\mathbf{B})$ and $M s \times 2^{+/-}(\mathbf{D})$ enamel is observed for the external prismatic enamel (between the dashed lines). Ms $x 2$-null mutants show a hypoplastic enamel dysplasia with absence of rods and many internal cracks (F). Compared to wild type (G), in $M s x 2^{+/-}$mutant mice the rods are modified $(\mathbf{H})$. Prism width was $1.9 \pm 0.2 \mu \mathrm{m}$ in wild-type mice, and $2.7 \pm 0.2 \mu \mathrm{m}$ in heterozygous mice, as established by analysis of 20 different areas of the inner prismatic enamel. The external prismatic enamel layer (EPE) is much larger in $M s x 2^{+/-}$than in $M s x 2^{+/+}$mice. E, enamel; D, dentin; R, resin; OAE, outer aprismatic enamel; IPE, inner prismatic enamel; IRo, inter-rod rod enamel.

enamel thickness and shifting of the rod/inter-rod proportion in favor of the rods was documented in $\mathrm{Ms} 2^{+/-}$mice (rods were enlarged to $2.7 \mu \mathrm{m}$ in the heterozygous genotype versus $1.9 \mu \mathrm{m}$ in wild type). Divergent phenotypes in vivo also suggest that amelogenin levels control enamel thickness and rods. In amelogenin ${ }^{-1-}$ mice, enamel is considerably reduced in thickness and loses its rod structure. ${ }^{23}$ This phenotype is also observed to a lesser extend in vitamin D-deficient rats, in which lower amelogenin levels led to a decrease in both the rod/interrod ratio and enamel thickness. ${ }^{39}$ Consistent with this, in secretion-stage ameloblasts, MSX2 (as shown previously for $\mathrm{DLX} 2^{43}$ ) was variably down-regulated, depending on the enamel thickness. The MSX2 (and DLX2 ${ }^{36}$ ) expression gradient mirrors the amelogenin and enamel thickness patterns.

The present study revealed a key role for MSX2 in amelogenin repression, and suggests two functions for MSX2 in vivo: i) up-regulation of MSX2 would limit amelogenin production and block enamel deposition in other cell stages and types than secretion stage ameloblasts; and ii) during the enamel matrix deposition, MSX2 controls enamel thickness and rod morphogenesis. In conclusion, MSX2 regulates enamel architecture, as previously documented for developmental genes in mineralizing tissues ${ }^{44}$ in our group.

\section{Physiopathological Triad of Hypoplastic Enamel Dysplasia in Msx2 $2^{-1-}$ Mice}

In $\mathrm{Ms} \mathrm{2}^{-1-}$ mice, the enamel, when present, presented a reduced thickness $(40 \pm 10 \mu \mathrm{m}$ versus $104 \pm 10 \mu \mathrm{m}$ in wild type) and displayed an irregular surface. Enamel was confined to an amorphous layer without rod architecture. Some cracks were observed in this thin enamel layer. Various genetic forms of amelogenesis imperfecta ${ }^{45}$ are secondary to mutations in human genes (enamelin, ${ }^{46}$ kallikrein $4,{ }^{47}$ and enamelysin ${ }^{48}$ ) and transgenic mouse lines. ${ }^{23,25,49-52}$ Among these clinical disorders and experimental models, the enamels of ${\mathrm{Ms} \times 2^{-1-} \text { and amelogenin }}^{-1-}$ mice harbor the most significant similarities, both corresponding to hypoplastic type of enamel defects. Similarly, enamelin null mutants show structural alterations in heterozygous mice and the absence of enamel in homozygous mutant mice ${ }^{53}$ Consistent with such phenotypes, the present RT-qPCR analysis revealed reduced expression of both amelogenin and enamelin in $\mathrm{Ms} \mathrm{2}^{-{ }^{--}}$ mouse dental epithelium, whereas ameloblastin mRNA expression was unaffected.

In addition to enamel matrix defects, ameloblast differentiation was impaired in Ms $\times 2^{-1-}$ mice. Ameloblasts lost their intercellular junctions, became round, and detached. Reduced amounts of mRNA encoding laminin $5 \alpha 3$ (as previously observed in situ $^{7}$ ) and cytokeratin 5 were observed by RT-qPCR. In humans, mutation of the laminin $5 \alpha 3$ gene leads to epidermolysis bullosa, which is associated with enamel dysplasia and impaired tooth eruption as observed in Msx2 null-mutant mice. ${ }^{6}$ Laminin 5 is implicated in cell-cell junctions during ameloblast differentiation. Ameloblast anchorage to secreted matrix, membrane and mineral is crucial for rod orientation, structure, and mineralization. ${ }^{54}$ Cytokeratin 5 is a component of intermediate filaments of epithelial tissues. Cytokeratin 5 binds to the amelogenin trityrosyl motif peptide (ATMP) sequence of amelogenin and is suspected to play a chaperone role for nascent amelogenin polypeptides. ${ }^{55}$ Thus, the reduction of cytokeratin 5 expression 
would additionally contribute to the enamel defects observed in Msx2 null mice.

Therefore, it may be concluded that the enamel dysplasia results from a physiopathological triad in $\mathrm{Ms} \times 2^{-{ }^{--}}$ mice: i) a progressive deficit of differentiated ameloblasts, which was shown here to vary between incisors and molars; ii) altered expression levels of cellular proteins involved in cell-cell junctions (laminin $5 \alpha 3$ ) and the amelogenin biosynthetic pathway (cytokeratin 5); iii) decreased levels of specific enamel-related species (amelogenin, enamelin, and DSPP, but not ameloblastin) in the extracellular matrix compartment.

\section{Overexpressed Enamel Proteins - Signals in Msx2 ${ }^{-1-}$ Mouse Periodontal Anomalies}

Amelogenin function seems not to be restricted to a structural role. The first evidence of amelogenin signal function via Runx 2 activation was supplied by Arthur Veis Dental School of the Aristotle University of Thessaloniki, Thessaloniki, Greece. ${ }^{29}$ A number of studies further supported this first experiment. Amelogenins are osteo-inductive in both fibroblasts ${ }^{29}$ and embryonic stem cells. ${ }^{30}$ In vitro studies assigned a function to amelogenins in cementum and alveolar bone remodeling. ${ }^{56-58}$ Immortalized cementoblasts exposed to amelogenin overexpress bone sialoprotein (BSP) in a dose-dependent manner. ${ }^{59}$ In bone cells, amelogenin severely inhibits osteoclastogenesis through down-regulation of RANKL, M-CSF, and fibronectin production by osteoblasts. ${ }^{60}$ Conversely, in vivo, amelogenin ${ }^{-1-}$ mice display cementum resorption and increased RANKL expression. ${ }^{23,31}$

In the periodontium of Msx2 null-mutant mice, regional osteopetrosis and delayed tooth eruption were previously reported. ${ }^{6}$ In the present study, transformation of ERMs into hypertrophic epithelial islands and neighboring hypercementosis were documented. This ended in young adults with the growth of cementum-bone-like tissue structures which entrapped giant epithelial islands within the roots. These epithelial cells appeared enlarged and produced amelogenin and ameloblastin even though enamel protein detection is technically difficult in postnatal periodontium at the basal level ${ }^{41,61}$. Evident enamel protein detection in epithelial root Malassez cells is related to physiopathological situations such as inflammation, ${ }^{62}$ cementum repair and, here, periodontal defects in Msx2 null mice. Alterations to dental hard tissues may have consequences in mastication function and could contribute to these periodontal defects.

Therefore, the MSX2 decreased and the overexpression of amelogenin and ameloblastin in continuously growing, giant epithelial islands and cells observed here play a role in the pluri-tissular alterations of $\mathrm{Ms} \times \mathrm{2}^{-1-}$ mouse periodontium: increased cementum, alveolar bone deposition (via increased Runx2 levels specifically in the alveolar bone, RT-qPCR data non shown), and decreased alveolar bone resorption (via decreased RANK-ligand levels). ${ }^{6}$

To conclude, $M s \times 2^{-1-}$ mice encompass phenotypic characteristics of both isolated enamel dysplasia, because of the severe reduced expression in enamel struc- ture genes (amelogenin, enamelin), and syndromic enamel dysplasia, through alterations in cell-cell junctions (laminin $5 \alpha 3$, cytokeratin 5). In addition, the enamel and periodontal phenotypes demonstrate a potential dual impact: both structural (enamel morphogenesis in

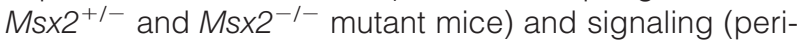
odontal positive balance in $M s \times 2^{-1-}$ mice) roles of enamel proteins in a physiopathological context.

\section{Acknowledgment}

We thank Benoit Robert for providing the Msx2/LacZ transgenic mouse line.

\section{References}

1. Alappat S, Zhang ZY, Chen YP: Msx homeobox gene family and craniofacial development. Cell Res 2003, 13:429-442

2. Catron KM, Wang H, Hu G, Shen MM, Abate-Shen C: Comparison of MSX-1 and MSX-2 suggests a molecular basis for functional redundancy. Mech Dev 1996, 55:185-199

3. Berdal A, Molla M, Hotton D, Aioub M, Lezot F, Nefussi JR, Goubin G: Differential impact of MSX1 and MSX2 homeogenes on mouse maxillofacial skeleton. Cells Tissues Organs 2009, 189:126-132

4. Catron KM, ller N, Abate C: Nucleotides flanking a conserved TAAT core dictate the DNA binding specificity of three murine homeodomain proteins. Mol Cell Biol 1993, 13:2354-2365

5. Satokata I, Ma L, Ohshima H, Bei M, Woo I, Nishizawa K, Maeda T, Takano Y, Uchiyama M, Heaney S, Peters H, Tang Z, Maxson R, Maas $\mathrm{R}$ : Msx2 deficiency in mice causes pleiotropic defects in bone growth and ectodermal organ formation. Nat Genet 2000, 24:391-395

6. Aioub M, Lezot F, Molla M, Castaneda B, Robert B, Goubin G, Nefussi JR, Berdal A: Msx2 -/- transgenic mice develop compound amelogenesis imperfecta, dentinogenesis imperfecta and periodontal osteopetrosis. Bone 2007, 41:851-859

7. Bei M, Stowell S, Maas R: Msx2 controls ameloblast terminal differentiation. Dev Dyn 2004, 231:758-765

8. Jabs EW, Muller U, Li X, Ma L, Luo W, Haworth IS, Klisak I, Sparkes $\mathrm{R}$, Warman ML, Mulliken JB, et al:: A mutation in the homeodomain of the human MSX2 gene in a family affected with autosomal dominant craniosynostosis. Cell 1993, 75:443-450

9. Wuyts W, Reardon W, Preis S, Homfray T, Rasore-Quartino A, Christians $\mathrm{H}$, Willems PJ, Van Hul W: Identification of mutations in the MSX2 homeobox gene in families affected with foramina parietalia permagna. Hum Mol Genet 2000, 9:1251-1255

10. Suda N, Kitahara Y, Ohyama K: A case of amelogenesis imperfecta, cleft lip and palate and polycystic kidney disease. Orthod Craniofac Res 2006, 9:52-56

11. Wu LY, Li M, Hinton DR, Guo L, Jiang S, Wang JT, Zeng A, Xie JB, Snead M, Shuler C, Maxson RE, Jr., Liu YH: Microphthalmia resulting from MSX2-induced apoptosis in the optic vesicle. Invest Ophthalmol Vis Sci 2003, 44:2404-2412

12. Liu YH, Kundu R, Wu L, Luo W, Ignelzi MA, Jr., Snead ML, Maxson RE, Jr.: Premature suture closure and ectopic cranial bone in mice expressing Msx2 transgenes in the developing skull. Proc Natl Acad Sci USA 1995, 92:6137-6141

13. Winograd J, Reilly MP, Roe R, Lutz J, Laughner E, Xu X, Hu L, Asakura T, vander Kolk C, Strandberg JD, Semenza GL: Perinatal lethality and multiple craniofacial malformations in MSX2 transgenic mice. Hum Mol Genet 1997, 6:369-379

14. Cheng SL, Shao JS, Cai J, Sierra OL, Towler DA: Msx2 exerts bone anabolism via canonical Wht signaling. J Biol Chem 2008, 283: 20505-20522

15. Newberry EP, Latifi T, Towler DA: Reciprocal regulation of osteocalcin transcription by the homeodomain proteins Msx2 and DIx5. Biochemistry 1998, 37:16360-16368

16. $\mathrm{Xu} Y$, Zhou YL, Erickson RL, Macdougald OA, Snead ML: Physical dissection of the CCAAT/enhancer-binding protein alpha in regulat- 
ing the mouse amelogenin gene. Biochem Biophys Res Commun 2007, 354:56-61

17. Cheng SL, Shao JS, Charlton-Kachigian N, Loewy AP, Towler DA: MSX2 promotes osteogenesis and suppresses adipogenic differentiation of multipotent mesenchymal progenitors. J Biol Chem 2003, 278:45969-45977

18. Ichida F, Nishimura R, Hata K, Matsubara T, Ikeda F, Hisada K, Yatani $\mathrm{H}$, Cao X, Komori T, Yamaguchi A, Yoneda T: Reciprocal roles of MSX2 in regulation of osteoblast and adipocyte differentiation. J Biol Chem 2004, 279:34015-34022

19. Lee MH, Kim YJ, Yoon WJ, Kim JI, Kim BG, Hwang YS, Wozney JM, Chi XZ, Bae SC, Choi KY, Cho JY, Choi JY, Ryoo HM: DIx5 specifically regulates Runx2 type II expression by binding to homeodomainresponse elements in the Runx2 distal promoter. J Biol Chem 2005, 280:35579-35587

20. Moradian-Oldak J: Amelogenins: assembly, processing and control of crystal morphology. Matrix Biol 2001, 20:293-305

21. Moradian-Oldak J, Du C, Falini G: On the formation of amelogenin microribbons. Eur J Oral Sci 2006, 114(Suppl 1):289-296, discussion 327-329, 382

22. Fowler CE, Beniash E, Yamakoshi Y, Simmer JP, Margolis HC: Cooperative mineralization and protein self-assembly in amelogenesis: silica mineralization and assembly of recombinant amelogenins in vitro. Eur J Oral Sci 2006, 114(Suppl 1):297-303, discussion 327329, 382

23. Gibson CW, Yuan ZA, Hall B, Longenecker G, Chen E, Thyagarajan T, Sreenath T, Wright JT, Decker S, Piddington R, Harrison G, Kulkarni AB: Amelogenin-deficient mice display an amelogenesis imperfecta phenotype. J Biol Chem 2001, 276:31871-31875

24. Fukumoto S, Kiba T, Hall B, lehara N, Nakamura T, Longenecker G, Krebsbach PH, Nanci A, Kulkarni AB, Yamada Y: Ameloblastin is a cell adhesion molecule required for maintaining the differentiation state of ameloblasts. J Cell Biol 2004, 167:973-983

25. Hu JC, Hu Y, Smith CE, McKee MD, Wright JT, Yamakoshi Y, Papagerakis P, Hunter GK, Feng JQ, Yamakoshi F, Simmer JP: Enamel defects and ameloblast-specific expression in Enam knock-out/lacz knock-in mice. J Biol Chem 2008, 283:10858-10871

26. MacDougall M, Nydegger J, Gu TT, Simmons D, Luan X, Cavender A, D'Souza RN: Developmental regulation of dentin sialophosphoprotein during ameloblast differentiation: a potential enamel matrix nucleator. Connect Tissue Res 1998, 39(1-3):25-37, discussion 63-67

27. Wright JT: The molecular etiologies and associated phenotypes of amelogenesis imperfect. Am J Med Genet A 2006, 140:2547-2555

28. Gruenbaum-Cohen Y, Tucker AS, Haze A, Shilo D, Taylor AL, Shay B, Sharpe PT, Mitsiadis TA, Ornoy A, Blumenfeld A, Deutsch D: Amelogenin in cranio-facial development: the tooth as a model to study the role of amelogenin during embryogenesis. J Exp Zool B Mol Dev Evol 2009, Jul 15; 312 B (5):445-457

29. Veis A, Tompkins K, Alvares K, Wei K, Wang L, Wang XS, Brownell AG, Jengh SM, Healy KE: Specific amelogenin gene splice products have signaling effects on cells in culture and in implants in vivo. J Biol Chem 2000, 275:41263-41272

30. Warotayanont R, Zhu D, Snead ML, Zhou Y: Leucine-rich amelogenin peptide induces osteogenesis in mouse embryonic stem cells. Biochem Biophys Res Commun 2008, 367:1-6

31. Hatakeyama J, Sreenath T, Hatakeyama $Y$, Thyagarajan $T$, Shum L, Gibson CW, Wright JT, Kulkarni AB: The receptor activator of nuclear factor-kappa B ligand-mediated osteoclastogenic pathway is elevated in amelogenin-null mice. J Biol Chem 2003, 278:35743-35748

32. Hatakeyama J, Philp D, Hatakeyama Y, Haruyama N, Shum L, Aragon MA, Yuan Z, Gibson CW, Sreenath T, Kleinman HK, Kulkarni AB: Amelogenin-mediated regulation of osteoclastogenesis, and periodontal cell proliferation and migration. J Dent Res 2006, 85:144-149

33. Zhou YL, Snead ML: Identification of CCAAT/enhancer-binding protein alpha as a transactivator of the mouse amelogenin gene. J Biol Chem 2000, 275:12273-12280

34. Bonass WA, Robinson PA, Kirkham J, Shore RC, Robinson C: Molecular cloning and DNA sequence of rat amelogenin and a comparative analysis of mammalian amelogenin protein sequence divergence. Biochem Biophys Res Commun 1994, 198:755-763

35. Hotton D, Davideau JL, Bernaudin JF, Berdal A: In situ hybridization of calbindin-D $28 \mathrm{k}$ transcripts in undecalcified sections of the rat continuously erupting incisor. Connect Tissue Res 1995, 32:137-143

36. Lezot F, Thomas B, Greene SR, Hotton D, Yuan ZA, Castaneda B,
Bolanos A, Depew M, Sharpe P, Gibson CW, Berdal A: Physiological implications of DLX homeoproteins in enamel formation. J Cell Physiol 2008, 216:688-697

37. Ghoul-Mazgar S, Hotton D, Lezot F, Blin-Wakkach C, Asselin A, Sautier JM, Berdal A: Expression pattern of DIx3 during cell differentiation in mineralized tissues. Bone 2005, 37:799-809

38. Zhou YL, Lei Y, Snead ML: Functional antagonism between Msx2 and CCAAT/enhancer-binding protein alpha in regulating the mouse amelogenin gene expression is mediated by protein-protein interaction. J Biol Chem 2000, 275:29066-29075

39. Papagerakis P, Hotton D, Lezot F, Brookes S, Bonass W, Robinson C, Forest $N$, Berdal $A$ : Evidence for regulation of amelogenin gene expression by 1,25 -dihydroxyvitamin $\mathrm{D}(3)$ in vivo. J Cell Biochem 1999, 76:194-205

40. Snead ML, Luo W, Lau EC, Slavkin HC: Spatial- and temporal-restricted pattern for amelogenin gene expression during mouse molar tooth organogenesis. Development 1988, 104:77-85

41. Janones DS, Massa LF, Arana-Chavez VE: Immunocytochemical examination of the presence of amelogenin during the root development of rat molars. Arch Oral Biol 2005, 50:527-532

42. Fong CD, Hammarstrom L: Expression of amelin and amelogenin in epithelial root sheath remnants of fully formed rat molars. Oral Surg Oral Med Oral Pathol Oral Radiol Endod 2000, 90:218-223

43. Lezot F, Descroix V, Mesbah M, Hotton D, Blin C, Papagerakis P Mauro N, Kato S, MacDougall M, Sharpe P, Berdal A: Cross-talk between Msx/DIx homeobox genes and vitamin D during tooth mineralization. Connect Tissue Res 2002, 43:509-514

44. Wurtz T, Berdal A: Osteoblast precursors at different anatomic sites. Crit Rev Eukaryot Gene Expr 2003, 13:147-161

45. Witkop CJ, Jr.: Amelogenesis imperfecta, dentinogenesis imperfecta and dentin dysplasia revisited: problems in classification. J Oral Pathol 1988, 17:547-553

46. Kim JW, Seymen F, Lin BP, Kiziltan B, Gencay K, Simmer JP, Hu JC: ENAM mutations in autosomal-dominant amelogenesis imperfecta. $J$ Dent Res 2005, 84:278-282

47. Wright JT, Daly B, Simmons D, Hong S, Hart SP, Hart TC, Atsawasuwan $\mathrm{P}$, Yamauchi M: Human enamel phenotype associated with amelogenesis imperfecta and a kallikrein-4 (g. 2142G $>$ A) proteinase mutation. Eur J Oral Sci 2006, 114(Suppl 1):13-17; discussion 39-41, 379

48. Ozdemir D, Hart PS, Ryu OH, Choi SJ, Ozdemir-Karatas M, Firatli E, Piesco N, Hart TC: MMP20 active-site mutation in hypomaturation amelogenesis imperfecta. J Dent Res 2005, 84:1031-1035

49. Paine ML, Wang HJ, Luo W, Krebsbach PH, Snead ML: A transgenic animal model resembling amelogenesis imperfecta related to ameloblastin overexpression. J Biol Chem 2003, 278:19447-19452

50. Paine ML, Zhu DH, Luo W, Bringas P, Jr., Goldberg M, White SN, Lel YP, Sarikaya M, Fong HK, Snead ML: Enamel biomineralization defects result from alterations to amelogenin self-assembly. J Struct Biol 2000, 132:191-200

51. Gibson CW, Yuan ZA, Li Y, Daly B, Suggs C, Aragon MA, Alawi F Kulkarni AB, Wright JT: Transgenic mice that express normal and mutated amelogenins. J Dent Res 2007, 86:331-335

52. Fukumoto S, Yamada A, Nonaka K, Yamada Y: Essential roles of ameloblastin in maintaining ameloblast differentiation and enamel formation. Cells Tissues Organs 2005, 181:189-195

53. Seedorf $\mathrm{H}$, Klaften M, Eke F, Fuchs $\mathrm{H}$, Seedorf U, Hrabe de Angelis $\mathrm{M}$ : A mutation in the enamelin gene in a mouse model. J Dent Res 2007, 86:764-768

54. Yoshiba K, Yoshiba N, Aberdam D, Meneguzzi G, Perrin-Schmitt F, Stoetzel C, Ruch JV, Lesot H: Expression and localization of laminin-5 subunits during mouse tooth development. Dev Dyn 1998, 211: $164-176$

55. Ravindranath RM, Basilrose RM, Sr., Ravindranath NH, Vaitheesvaran B: Amelogenin interacts with cytokeratin- 5 in ameloblasts during enamel growth. J Biol Chem 2003, 278:20293-20302

56. Boabaid F, Gibson CW, Kuehl MA, Berry JE, Snead ML, Nociti FH, Jr., Katchburian E, Somerman MJ: Leucine-rich amelogenin peptide: a candidate signaling molecule during cementogenesis. J Periodontol 2004, 75:1126-1136

57. Swanson EC, Fong HK, Foster BL, Paine ML, Gibson CW, Snead ML, Somerman MJ: Amelogenins regulate expression of genes associated with cementoblasts in vitro. Eur J Oral Sci 2006, 114(Suppl 1):239-243; discussion 254-256, 381-382 
58. Zeichner-David M, Chen LS, Hsu Z, Reyna J, Caton J, Bringas P: Amelogenin and ameloblastin show growth-factor like activity in periodontal ligament cells. Eur J Oral Sci 2006, 114 Suppl 1:244-253; discussion 254-256, 381-382

59. Viswanathan HL, Berry JE, Foster BL, Gibson CW, Li Y, Kulkarni $A B$, Snead ML, Somerman MJ: Amelogenin: a potential regulator of cementum-associated genes. J Periodontol 2003, 74:14231431

60. Nishiguchi M, Yuasa K, Saito K, Fukumoto E, Yamada A, Hasegawa T, Yoshizaki K, Kamasaki Y, Nonaka K, Fujiwara T, Fukumoto S:
Amelogenin is a negative regulator of osteoclastogenesis via downregulation of RANKL. M-CSF and fibronectin expression in osteoblasts. Arch Oral Biol 2007, 52:237-243

61. Mizuno N, Shiba H, Mouri Y, Xu W, Kudoh S, Kawaguchi H, Kurihara $\mathrm{H}$ : Characterization of epithelial cells derived from periodontal ligament by gene expression patterns of bone-related and enamel proteins. Cell Biol Int 2005, 29:111-117

62. Hamamoto $Y$, Nakajima T, Ozawa H, Uchida T: Production of amelogenin by enamel epithelium of Hertwig's root sheath. Oral Surg Oral Med Oral Pathol Oral Radiol Endod 1996, 81:703-709 